ISSN 1412-2936

EISSN 2549-7308

\title{
INTEGRATED MARKETING STRATEGY FOR BEVERAGES FRANCHISE INDUSTRY
}

\author{
Mohammad Hamim Sultoni \\ hamimsultoni@gmail.com \\ State Islamic Institute of Madura
}

\begin{abstract}
Trend of food and beverage industry in Asian market shows a positive growth. it is showed that nominal growth in the region over the next five years is expected to average $9 \%$ per year compared to a global average of $6.4 \%$ per year. Cokelat Klasik as a business in the F\&B line optimistic to fight in the market and competition. For over eight-monthsoperation, Cokelat Klasik has a main hypothesis problem about the unreached target sales. According to the data, percentage of reachable target sales of Cokelat Klasik is $54 \%$ and is still unreached target sales. So, this research have goals to know the effective marketing strategy that's can be implemented for the next step. The approach used is qualitative methods. The depth-interview will be primary data to collect information from external environment. Then, literature review is also used to support analysis as secondary data. Internal data will be analyzed using Business Model Canvas, 4Ps Analysis, STP (Segmenting, Targeting, and Positioning) and Strength \& Weakness. External data will be analyzed using the Porter Five Forces, Competitor Analysis and Opportunity \& Threat. Then, the internal data and external data will be analyzed in TOWS Matrix. The proposed solution is derived from the new marketing mix and Program of Integrated Marketing Communications (IMC). The element of IMC that's used is consist of six tools, which are: advertising, sales promotion, event and sponsorship, direct marketing, and digital/internet marketing. The implementation plan is set on one year periods which is from Sept 2017 until August 2018.
\end{abstract}

Keywords: Marketing Strategy, Beverages Business, Business Strategy 


\section{A. INTRODUCTION}

\section{Background}

Food and beverage businesses have various forms of business models. When it is viewed according to the business unit, the business model that runs on the culinary industry can be divided into three categories: independent, chain, and franchise. The object of this research is culinary industry in the form of beverage business employing franchise concept. Definition of franchise based on Government Regulation No. 16 in 1997 is an engagement when one party is granted the right to utilize and/or use Intellectual Property Rights or the meetings of typical business owned by another party with a reward based on the requirements set by the other party in order to provide goods and services.

Trend of food and beverage industry in Asian market shows a positive growth. According to data from PWC on 2015-16 Outlook for the Retail and Consumer Product, it is showed that nominal growth in the region over the next five years is expected to average $9 \%$ per year compared to a global average of $6.4 \%$ per year. By 2018, Asia will account for $60 \%$ of global consumer expenditure in this category, with its share which is worth US $\$ 5,9$ trillion compared with US\$3,9 trillion in 2014 .

Street beverages are retail trade that sells and serve product which are ready to be moved or dismantled pairs, usually by using a tent, such as coffee shops, Juice shops and other beverages (Mississippi Development, 2011). Global production of cocoa is currently forecast to decrease for the third year in a row $2015 / 16$ production is expected at 4.1 million tons vs. $2014 / 15$ production of 4.2 million tons. $2013 / 14$ production was 4.3 million tons. Chocolate is broadly classified by the amount of cocoa it contains. Milk chocolate accounts for more than $50 \%$ of all chocolate consumption but may contain as little as $10 \%$ cocoa. Hershey's milk chocolate has approximately $11 \%$ cocoa, with a whole lot of milk and sugar added in. Chocolate is considered "dark" if it has more than 60\% cocoa. (Chocolate Industry, 2017).

Based on theory, franchise is a marketing channel structure intended to convince end users that they are buying product from a vertically integrated manufacturer when, in fact, they may be buying from a separately owned company (Coughlan, 2006). Business development using franchise system makes distribution of partnership in many areas. It will be one of the issues for franchisor because the system should be similar in every branch. But, in fact, every city has different culture which might influences consumers' behavior in there. Besides, it will also influence the growth of sales and market penetrations. Cokelat Klasik Bandung needs to propose new marketing strategy to reach target sales.

\section{Company History}

Cokelat Klasik Bandung is a branch of CV. Klasik in Bandung. Since July 2016, this business began to operate with legal entity as a franchise partner. Cokelat Klasik Bandung is the first branch as well as the only one in Bandung. As a franchisee, business activity is more dominant focused on the operations and marketing strategy to the consumers. The concept of layout used is "Booth Concept". It is positioned as street beverages so that it will be closer and reachable for consumers. In addition, booth layout using wood shows the impression of ethnic, nature, and classic.

As a franchise partner of CV Klasik, Cokelat Klasik Bandung has more simple business activities than them. Business activity is focused on operation process and marketing 
ISSN 1412-2936

EISSN 2549-7308

strategy to the end user. The stages of business activity are as follows:

\section{Stage 1: Production Material}

The main material like a chocolate powder have been available and supplied by CV. Klasik. However, the others supporting materials are acquired or purchased around Bandung.

\section{Stage 2: Operations Process}

Products of Cokelat Klasik are kinds of products "Made by order". So, the product is produced by request. The operations process in a single product can be explained in the figure below:

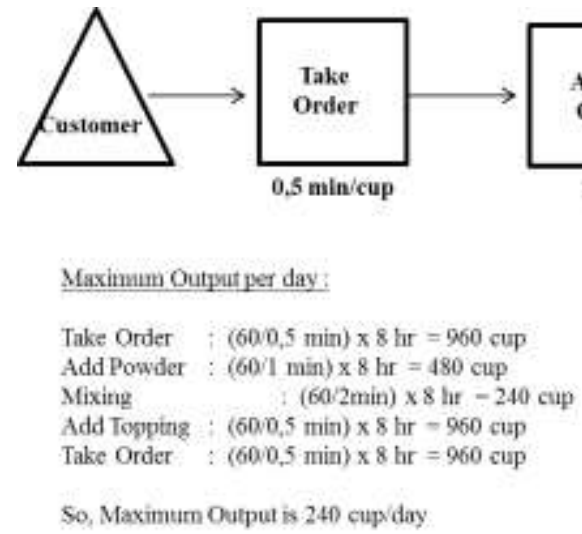

Stage 3: Marketing

In general, Cokelat Klasik Bandung has market segmentation to the consumers in Bandung area. The main target of Cokelat Klasik Bandung is college student at Parahyangan University and consumers in radius of $5 \mathrm{~km}$ from business location. So, the current marketing activities are more focused on programs to attract consumers with offline marketing

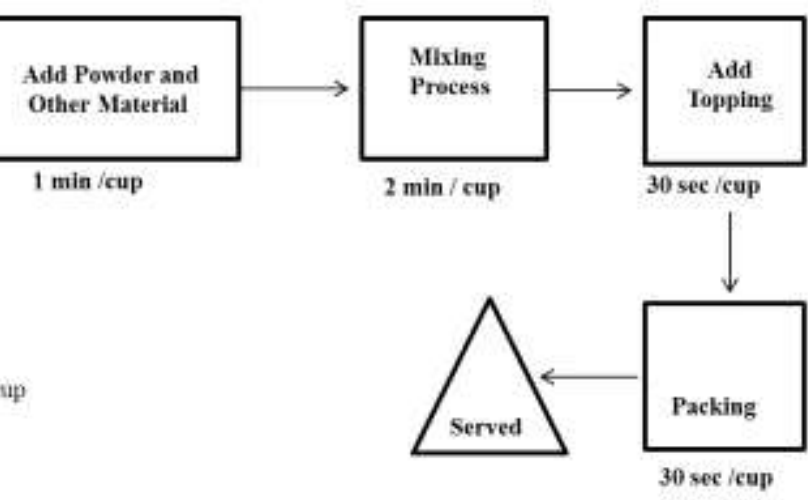

Figure 1 Operations Process (Company Data) strategy such as discount, free trial, buy one get one free, and member card.

\section{Business Issue}

For over eight-monthsoperation, Cokelat Klasik has a main hypothesis problem about the unreached target sales. The hypothesis can be supported by sales data in other competitor around radius of $1 \mathrm{~km}$ from business location. The data are as follows Table 1 :

Table 1 Data Survey of Quantity Sales Competitor in April 2017

\begin{tabular}{l|l|c|c|c|c|c}
\hline No & Competitor & $\begin{array}{c}\text { Target } \\
\text { Sales/day }\end{array}$ & $\begin{array}{c}\text { Qty sales } \\
\text { min/day }\end{array}$ & $\begin{array}{c}\text { Qty sales } \\
\text { max/day }\end{array}$ & $\begin{array}{c}\text { Avg } \\
\text { sales / } \\
\text { week }\end{array}$ & $\begin{array}{c}\% \text { of } \\
\text { Reachable } \\
\text { Target }\end{array}$ \\
\hline 1 & Juice for you & 150 & 140 & 190 & 159 & $100 \%$ \\
\hline 2. & The Poci & 60 & 50 & 68 & 58 & $96 \%$ \\
\hline 3. & Cokelat Klasik & 50 & 20 & 32 & 27 & $54 \%$ \\
\hline
\end{tabular}

According to the data in table above, Percentage of reachable target sales of Cokelat Klasik is $54 \%$ and is still unreached target sales. So, from this data analysis and hypothesis problems, Cokelat Klasik will try to find the real problem that should be solved. Then, a means of root cause analysis which can be used to find a real problem is by using structure tree analysis/ fault tree analysis. In sum, the following are the most likely root cause of sales growth that has not reach the target. However, in this 
ISSN 1412-2936

EISSN 2549-7308

research only focused on the low effectiveness of marketing.

\section{B. LITERATURE REVIEW}

\section{Conceptual Framework}

Cokelat Klasik Bandung is a newcomer in culinary business. As the start-up which has many challenges and problems, identification of problems which is combined with the analysis of internal and external factor is needed to give the best solution. Then, conceptual framework is provided to guide this research and will be describes in the figure 2 below

\section{CONCEPTUAL FRAMEWORK}

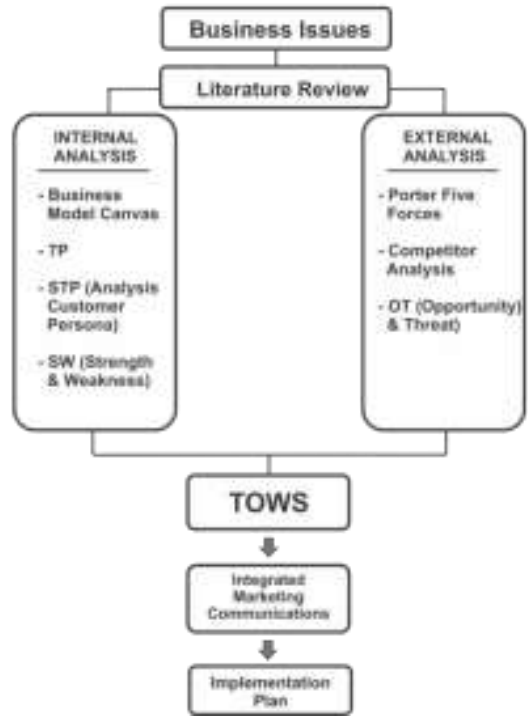

Figure 2 Conceptual Framework

2. Analysis of Business Situation

To analyze the internal factor of business, Cokelat Klasik Bandung employs BMC as a means of business model analysis. The explanation is described Figure 3 below:

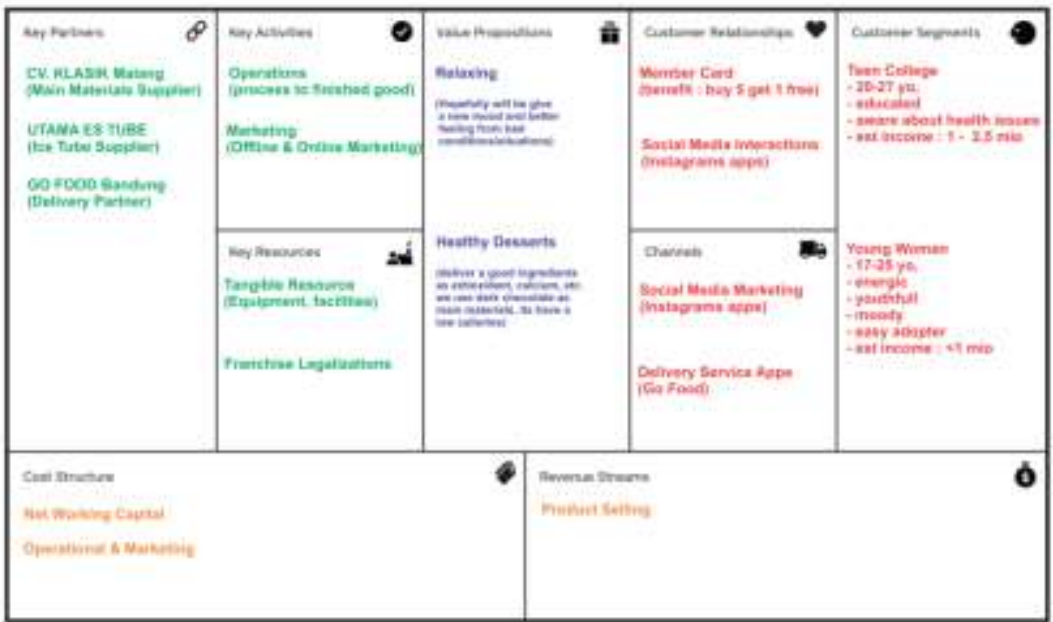

Figure 3 BMC of Cokelat Klasik Bandung 
ISSN 1412-2936

EISSN 2549-7308

Strength and weakness are part of internal analysis to know what positive and negative aspects in our internal factors. Basically, strength and weakness are analyzed based on SWOT Analysis. The explanation about strength and weakness is described in the table 1 below.

Table 1 Strength and Weakness Analysis

\begin{tabular}{l|l}
\hline \multicolumn{1}{c|}{ Strength } & \multicolumn{1}{c}{ Weakness } \\
\hline $\begin{array}{l}\text { S1: Clear value preposition: healthy dessert } \\
\text { and reduce bad feeling }\end{array}$ & W1: Unclear management inventory \\
\hline $\begin{array}{l}\text { S2: Different in terms of main materials } \\
\text { used which is dark chocolate }\end{array}$ & $\begin{array}{l}\text { W2: Supplier cannot make sure about } \\
\text { availability of raw material }\end{array}$ \\
\hline $\begin{array}{l}\text { S3: Good maintenance of chocolate powder } \\
\text { materials }\end{array}$ & $\begin{array}{l}\text { W3: Employee performance: } \\
\text { responsiveness and empathy }\end{array}$ \\
\hline S4: Clear standard of product making & $\begin{array}{l}\text { W4: Lack of financial and marketing } \\
\text { process to keep the quality of product }\end{array}$ \\
planning
\end{tabular}

External factor and environment of business change rapidly. One of the best ways to evaluate opportunity and threat is by capitalizing alternative

opportunity or minimizing the impact of threat. Then, the analysis of external factor is explained in the table 2 below:

Table 2 Opportunity and Threat Analysis

\begin{tabular}{l|l}
\hline \multicolumn{1}{c|}{ Opportunity } & \multicolumn{1}{c}{ Threat } \\
\hline $\begin{array}{l}\text { O1: Large number of market size and } \\
\text { growth in culinary business }\end{array}$ & $\begin{array}{l}\text { T1: Recipe of product and business } \\
\text { concept are easy to imitate }\end{array}$ \\
\hline $\begin{array}{l}\text { O2: Trend of social media and delivery } \\
\text { through online channel }\end{array}$ & $\begin{array}{l}\text { T2: Unpredictable climate: rainy season } \\
\text { will affect the sales of product }\end{array}$ \\
\hline $\begin{array}{l}\text { O3: Growth of target market which is } \\
\text { aware about healthy product }\end{array}$ & $\begin{array}{l}\text { T3: High growth of new entrants for the } \\
\text { same business line }\end{array}$ \\
\hline $\begin{array}{l}\text { O4: Chance to cooperate with retail for } \\
\text { mass distributions }\end{array}$ & $\begin{array}{l}\text { T4: Unpredictable tax regulation from the } \\
\text { government }\end{array}$ \\
\hline & $\begin{array}{l}\text { T5: New comers with more convenience } \\
\text { concept: café, working space, food court. }\end{array}$ \\
\hline
\end{tabular}

\section{METHOD, DATA, AND ANALYSIS}

The approach used is qualitative methods. The literature review will be primary data to collect information from scientific resource. Then, data collection also used to support analysis as secondary data. In this research, the researcher will used personal interviews as the method. Personal interview method requires a person known as the interviewer asking questions generally in a face-to- face contact to the other person or persons (Kothari, 2004).

Based on research objectives, this research needs information to analyze external stakeholders who can give insight to suggest marketing strategy. So, researcher uses a purposive sampling to choose interviewee that can give the information needed. Those criteria of interviewees are shown in table 3 below: 
ISSN 1412-2936

EISSN 2549-7308

Table 3 Criteria of Interviewee and Topic of Interview

\begin{tabular}{|c|c|c|c|}
\hline No & Interviewee & Topics & Numbers \\
\hline 1. & $\begin{array}{l}\text { Customer } \\
\text { - Persona } 1 \\
\text { - Persona } 2 \\
\text { - Persona } 3 \\
\end{array}$ & $\begin{array}{l}\text { - Product } \\
\text { - Price } \\
\text { - Place } \\
\text { - Service }\end{array}$ & 12 \\
\hline 2. & $\begin{array}{l}\text { Competitor: } \\
\text { - Juice For You } \\
\text { - Nyoklat Klasik } \\
\text { - Chocolate Changer }\end{array}$ & $\begin{array}{l}\text { - Business history } \\
\text { - Opportunity and Threat } \\
\text { - Trends of market } \\
\text { - Marketing Activity }\end{array}$ & 3 \\
\hline
\end{tabular}

The information from all of interviewee will be combined with other analysis result in chapter of discussion.

\section{RESULT AND DISCUSSION}

\section{Product}

There are several weaknesses in the products which should be solved and fixed by Cokelat Klasik. There are as follows:

1) Make an innovation in the product with the addition of two variants or two choices of tastes which are sweet and bitter

2) Redesigning the cup to be simpler and more elegant as well as modifying the shape of the cup so that it will not be spilled because the cover is not well-closed.

3) Fixing product stock management to fulfill the availability of the product and to reduce the possibility of the empty stock.

\section{Price}

There are several weaknesses in the price of product which should be solved and fixed by Cokelat Klasik. There are as follows:

1) Making an alternative product with the estimated price which is more affordable for schoolchildren.
2) Recounting the Cost of Goods Sold (COGS) product to ensure the efficiency of the raw material cost and reduce unnecessary cost.

3) Arranging strategy concerning on the price in sales promotion program such as voucher and price bundling.

\section{Place}

There are several weaknesses in the business location which should be solved and fixed by Cokelat Klasik such as follows:

1) Ensuring that the position of the booth is not blocked by other booths and giving a distinct banner or name board.

2) Providing extended roof in front of the booth so that the customers queuing might take shelter and do not feel stiflingly hot.

3) Ensuring that the ditch in front of the booth is not clogged and dirty as well as it does not smell bad.

\section{Promotion / Integrated Marketing Communication}

The key tools of promotion mix that used consist of six tools, which are: advertising, sales promotion, event and sponsorship, direct marketing, and digital/internet marketing. The Integrated Marketing Communication Plan can be strategy to answer marketing objectives of Cokelat Klasik Bandung. 


\section{CONCLUSION}

The point that can be reason why Cokelat Klasik unable to reach the target sales is Mostly interviewee said they never know about the promotion activity

for Cokelat Klasik. The key tools of or programs has been done before. Other result show the content/information of product is not clear. So, Integrated Marketing Communications (IMC) will be new marketing

strategy which is used for this research is

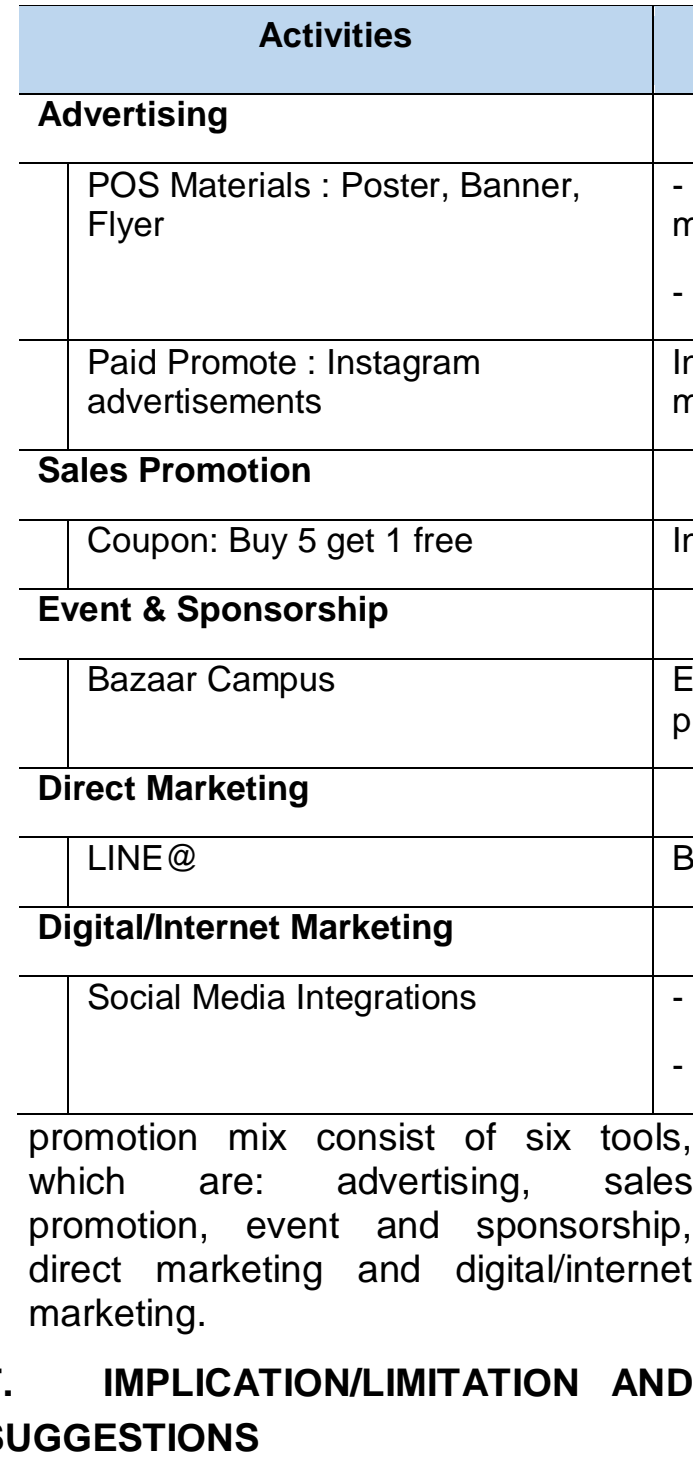

The researcher will limit the issues on aspects below:

1. This discussion is limited to the variable of Integrated Marketing Strategy for Cokelat Klasik Bandung.

2. The research object and location is Cokelat Klasik Bandung which has been operated for 8 month since July 2016 until February 2017. Then, the data company
Goals

Increasing brand awareness owned by target market (radius $1 \mathrm{~km}$ from business locations)

- Introducing a new variance

Increasing brand awareness owned by target market in Bandung area

ncreasing frequency and quantity of purchase

Engaging and involving targeted audience to try product or brand

Build customer relationship and engagement

Maintain and share the information about produt

Increase awareness and brand recognition

based on that period of business.

3. The location of research carried out in Ciumbuleuit area or radius 3 $\mathrm{km}$ from business location. Whereas, the location limits are in the area of Bandung.

\section{G. REFERENCE}

Bandung Climate in May 2017 at https://www.meteoblue.com/en/ weather/forecast/ modelclimate/bandung_indones ia_1650357 (Accessed : 5 March 2017)

Belch, George E., Belch, Michael A. 2009. Advertising and Promotion : An Integrated Marketing Communication 
ISSN 1412-2936

EISSN 2549-7308

Perspective. 8th Edition. New York : Mc Graw-Hill

Biro Pusat Statistik, 2015, Rata-Rata Pengeluaran per bulan daerah perkotaan, 11010001: p.496

Coughlan T. Anne \& Anderson, Erin. 2006, Marketing Channels (7th ed.), New Jersey: Pearson Prentice Hall.

Chattaraman, V. L. 2008. Ethnic identity, consumption of cultural apparel, and self-perceptions of ethnic consumers. Journal of Fashion Marketing and Management, 12(4), 518-531.

Chocolate Industry Analysis 2017Cost \& Trends. Available at: https://www.franchisehelp.com/i ndustry-reports/chocolateindustry-report/ (Accessed: 01 June 2017).

Duncan, Tom. 2005. Principle of Advertising and Integrated Marketing Communications. New York : Mc Graw Hill

Fuchs, C., et, al (2010). Theoretical Foundations of the Web: Cognition, Communication, and Co-Operation. Towards an Understanding of Web 1.0, 2.0, 3.0

Goetzinger, L., Lee, Y. J., \& Widdows, R. (2007). Valuedriven consumer e-health information search behavior. International Journal of Pharmaceutical and Healthcare Marketing, 1(2), 128-142.

Grant, Robert M. 2010. Contemporary Strategy Analysis 7th Editions. UK : John Wiley \& Sons Ltd

https://en.wikipedia.org/wiki/Cappucci no (Accessed: 3 May 2017, 8:17). http://www.business2community.com/mar keting/use-porters-five-forceswide

n-view-competitive-forces (Accessed: 3 May 2017, 9:12).

Indonesia Investment 2016 Food \& Beverages Industry of Indonesia : Positive Outlook. Available at: http://www.indonesiainvestments.com/id/news/today s-headlines/ food-beverageindustry-of-indonesia-positiveoutlook/item7135? (Accessed: 05 Feb 2017).

Jain, Manoj Kumar. 2013. An Analysis of Marketing Mix: 7Ps or More. Asian Journal of Multidisciplinary Studies Vol 1 , Issue 4, p. 23-28.

Kotler, P. \& Keller. 2005. Marketing Management. 8th Ed. New Jersey : Pearson Education

Kotler, P. \& Keller. 2012. Marketing Management. 14th Ed. New Jersey : Pearson Education

Louis Boone, D. K. 2010. Elements of the promotional mix: accessed from https://en.wikipedia.org/wiki/Pro motional mix

Merisavo, Marko. 2006. The Effects of Digital Marketing Communication on Customer Loyalty : An Integrative Model and Research Propositions. Helsinki School of Economics Paper PL 1210, Finland

Mississippi Development Authority. 2011. Mississippi's Creative Economy. Mississippi: Mississippi Development Authority

Osterwalder, A. \& Pigneur, Y. 2009. Business Model Generation. Self Published. 
ISSN 1412-2936

EISSN 2549-7308

PwC Coopers Limited, 2015. 2015-16 Outlook for the Retail and Consumer Product Sector in Asia. 16-17

Slavik, S. 2011. Analysis of Business Models. Journal of Competitiveness Vol 6, pp. 1940

Teece, J. D. 2010. Business Models, Business Strategy and Innovation. Long Range Planning, 43(2), 172-194. http://dx.doi.org/10.1016/j.Irp.20 $\underline{09.07 .003}$

Wilson, Richard MS. 2005. Strategic Marketing Management, 3rd Ed. Oxford : Elsevier 